\title{
From Theory To Practice: Recommending Supportive Diversity Practices
}

Marie-Élène Roberge, Northeastern Illinois University, USA

Roy J. Lewicki, Ohio State University, USA

Amy Hietapelto, Northeastern Illinois University, USA

Aijana Abdyldaeva, Northeastern Illinois University, USA

\begin{abstract}
Today, organizations must find effective solutions to the challenges brought by diversity. Research suggests that implementing supportive diversity practices help diverse organizations to adapt and sustain by creating a climate for diversity. Based on research and theory, the paper recommends five categories of supportive diversity practices: (1) Using symbolic management to value diversity, (2) Implementing training programs, (3) Implementing cross-functional teams, (4) Stimulating improved communication flow, and lastly (5) Promoting fairness in human resource practices.
\end{abstract}

Keywords: diversity practices; diversity management

\section{INTRODUCTION}

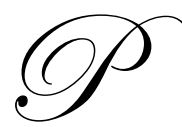

ractitioners and scientists often come to the conclusion that managing diversity in organizations is not an easy task (Ployhart, 2006; Richard, Kochan, \& McMillan-Capehart, 2002). This happens because diversity dynamics are frequently a breeding ground for different types of conflicts, such as misunderstandings, discriminatory behaviors, or antisocial behaviors (Shore, Chung-Herrera, Dean, Ehrhart, Jung, Randel \& Singh, 2009; Williams \& O'Reilly, 1998). Diversity refers to differences between individuals on any attributes that may lead to the perception that another person is different from the self (Jackson, 1992; Triandis, Kurowski, \& Gelfand, 1994; van Knippenberg, De Dreu, \& Homan, 2004; Williams \& O'Reilly, 1998). These attributes of interest may refer to demographic characteristics, informational/functional characteristics, personality traits, personal values, religious beliefs, sexual orientation, or mental and physical health and abilities. Being able to integrate and manage diverse people appropriately in the workplace has become more than ever before an important concern for managers.

This paper provides practical guidance to different level of management (i.e., senior managers, HR managers and line managers) about how to effectively manage diversity in order to reveal its full potential. The potential of managing diversity effectively may refer to enhancing organizational performance, by increasing employees' retention, improving corporate image, and enlarging share market, while decreasing legal liability, absenteeism, and employees' turnover. In this paper, we recommend five categories of strategic managerial practices that help, once implemented, to effectively manage diverse organizations. These five categories are: (1) Using symbolic management to value diversity, (2) Implementing training programs, (3) Implementing cross-functional teams, (4) Stimulating improved communication flow, and lastly (5) Promoting fairness and justice in human resource practices.

One major contribution of this paper is to go beyond the previous "prescriptive managerial actions". Previous work identifying managerial practices related to diversity management has not been as fully grounded in theory as it could and should have been (Jamieson \& O'Mara, 1991). This paper contributes to the field by explaining how research and theory can be utilized to understand the complexity of diversity management and by recommending the implementation of a combination of strategic managerial practices. The paper proposes five categories of strategic managerial practices that have their foundation in Organizational Behavior, Human Resource 
Management and Social Psychology research and theories such as social identity theory (Tajfel, \& Turner, 1986), self-categorization theory (Turner, Hogg, Oakes, Reichers, \& Wetherell, 1987), self-verification theory (Swann, Polzer, Seyler, \& Ko, 2004; Swann, Rentfrow, \& Guinn, 2005) and justice theory (Lind, 1998). Another major contribution of this paper is that it illustrates each strategic managerial practice by providing applied examples of organizations that successfully embrace diversity and effectively implement the recommended practices.

\section{THE RECOMMENDED PRACTICES TO MANAGE DIVERSITY EFFECTIVELY}

How can managers become more effective at managing diversity in organizations? In order to answer this question, today's organizations must invest the time and efforts to find the best managerial practices they can. According to the 2005 Survey Report about Workplace Diversity Practices conducted by the Society for Human Resource Management, $76 \%$ of HR professionals reported that their organizations had practice(s) in place that addressed workplace diversity. Almost all large-staff sized organizations (94\%) and fewer small (60\%) and medium (71\%) organizations reported implementing diversity practices.

Even though implementing diversity practices has become popular, organizations must continue to carefully examine their current practices and recognize if they are managing diversity superficially prior to defending themselves of such actions in front of the Court System (James \& Wooten, 2006). Facing a discrimination lawsuit is usually extremely costly for the organization and its stakeholders (Selmi, 2003). For example, the overall cost of the Texaco discrimination case exceeded $\$ 500$ million (Pruitt \& Nethercutt, 2002). Thus, managing diversity superficially or cosmetically (Hyde \& Hopkins, 2004), as opposed to managing it authentically, might backfire and therefore decrease organizational performance.

Managing diversity effectively in organizations refers to the process of creating and maintaining a workplace free of discrimination where stakeholders (i.e., employees, customers, suppliers, investors, and people from the local or global community), regardless of their differences (i.e., based on gender, culture, religion, expertise, personality etc.), feel included and supported. This process is very complex and delicate, and thus requires managers' full attention toward the implementation of appropriate practices and supportive activities that will, over time, improve organizational performance. Organizations must adopt strategic managerial actions and human resource practices that increase diversity awareness, and prevent or resolve diversity-related conflicts. Research suggests that implementing supportive diversity practices help to create a positive organizational climate for diversity, which, in turn, increase organizational attachment, reduce employees' absenteeism and turnover, and enhance organizational performance (McKay, Avery, \& Morris, 2009; Gonzalez \& Denisi, 2009). Indeed, strategic managerial and human resource practices are considered important moderators of the relationship between diversity and organizational performance. Research suggests that when organizational strategy and HR practices support diversity related programs and activities, diverse organizations are more likely to lead to positive performance outcomes (Kochan, Bezrukova, Ely, Jackson, Joshi, Jehn, Leonard, Levine and Thomas, 2003).

Table 1 identifies the five recommended strategic managerial practices and their respective supportive diversity activities, and it summarizes the influence of each practice on the psychological processes and performance outcomes.

In the following sections, each of the five recommended strategic managerial practices and their respective supportive diversity activities will be described and their influence on creating a positive climate for diversity will be discussed. Moreover, several applied examples will be provided to illustrate the implementation of each practice in current organizations. 
Table 1. Five Categories Of Supportive Diversity Programs And Activities And Their Related Effects On Psychological Processes And Performance Outcomes.

\begin{tabular}{|c|c|c|c|c|}
\hline Managerial Practices & Programs And Activities & $\begin{array}{c}\text { Individual And } \\
\text { Group Psychological } \\
\text { Processes } \\
\end{array}$ & $\begin{array}{l}\text { Organizational } \\
\text { Process }\end{array}$ & $\begin{array}{l}\text { Performance } \\
\text { Outcomes }\end{array}$ \\
\hline $\begin{array}{l}\text { Using symbolic } \\
\text { management }\end{array}$ & $\begin{array}{l}\text { - Expressing the value of } \\
\text { diversity in the mission } \\
\text { statement. } \\
\text { - Explaining why diversity } \\
\text { must be valued. } \\
\text { - Redefining the group } \\
\text { boundaries "US" rather the } \\
\text { "WE" versus "THEM". }\end{array}$ & \multirow{5}{*}{$\begin{array}{l}\text { Fostering a common } \\
\text { identity and pro- } \\
\text { diversity beliefs. } \\
\text { Developing diversity } \\
\text { awareness and trust. } \\
\text { Supporting self- } \\
\text { disclosure \& } \\
\text { Intergroup } \\
\text { communication. } \\
\text { Promoting cross- } \\
\text { functional } \\
\text { collaboration. } \\
\text { Improving } \\
\text { perceptions of justice. }\end{array}$} & \multirow{5}{*}{$\begin{array}{l}\text { Positive climate for } \\
\text { diversity. }\end{array}$} & \multirow{5}{*}{$\begin{array}{l}\text { Increases } \\
\text { individual } \\
\text { performance } \\
\text { (i.e., reduce } \\
\text { absenteeism, and } \\
\text { employees' } \\
\text { turnover). }\end{array}$} \\
\hline $\begin{array}{l}\text { Training programs and } \\
\text { activities }\end{array}$ & $\begin{array}{l}\text { - Socialization training. } \\
\text { - Cross-training. } \\
\text { - Team building. }\end{array}$ & & & \\
\hline $\begin{array}{l}\text { Stimulating } \\
\text { communication flow }\end{array}$ & $\begin{array}{l}\text { - Celebrating diversity. } \\
\text { - Brainstorming. } \\
\text { - Benchmarking. } \\
\end{array}$ & & & \\
\hline $\begin{array}{l}\text { Implementing cross- } \\
\text { cutting groups }\end{array}$ & $\begin{array}{l}\text { - Implementing } \\
\text { multidisciplinary teams. } \\
\text { - Social groups (meetings) } \\
\text { across the organization. }\end{array}$ & & & \\
\hline $\begin{array}{l}\text { Promoting fair and just } \\
\text { HR practices }\end{array}$ & $\begin{array}{l}\text { - Aligning HR to support } \\
\text { diversity: } \\
\circ \text { Recruitment. } \\
\circ \text { Selection. } \\
\circ \text { Performance } \\
\\
\text { evaluation. }\end{array}$ & & & \\
\hline
\end{tabular}

\section{Using Symbolic Management}

Symbolic management has been defined as the way management frames and portrays the organization to its members and other stakeholders (Fiss \& Zajac, 2006). Managers use symbolic language to focus on what is central, distinctive, and relatively enduring about the organization (Albert \& Whetten, 1985). According to the social identity theory (Tajfel \& Turner, 1986), self-categorization theory (Turner et al. 1987) as well as research on "groupthink" (Janis, 1982), emphasizing commonalities among diverse group members is a key condition to increase the likelihood that diversity will lead to positive outcomes (Brewer, \& Brown, 1998; Brewer \& Gaertner, 2004). More precisely, research has proposed that by restructuring or redefining group boundaries at a higher level of category inclusiveness [also called a super-ordinate category], these actions create a common ingroup identity which may reduce the negative consequences of diversity (Allport, 1954). Consistently, the common ingroup identity model (Gaertner \& Dovidio, 2000; Gaertner, Dovidio, Anastasio, Bachman, \& Rust, 1993; Gaertner, Dovidio, Nier, Ward, \& Banker, 1999) proposes that intergroup biases can be reduced by implementing practices that transform people' representations of memberships from multiple groups to one group, a more inclusive group (i.e. "us" instead of "we" and "they") (Brewer \& Gaertner, 2004). Thus, research suggests that managers may minimize or overcome conflicts and negative outcomes in diverse organizations, by framing a collective identity or an organizational identity through the usage of symbolic management that embodies the principle of believing in the value of diversity (Cox, 1993; Cox, Lobel, \& McLeod, 1991; Roberge \& van Dick, forthcoming). Believing in the value of diversity can also refer to pro-diversity beliefs (van Dick, van Knippenberg, Hägele, Guillaume, \& Brodbeck, 2008), openness to diversity (Hobman, Bordia, \& Gallois, 2004), or diversity perspectives (Ely \& Thomas, 2001). For example, currently Chief Diversity Officer at Deloitte, John Zamora believes that diversity is "a competitive business advantage that will pave the way to achieving Deloitte's vision of becoming the standard of excellence" (Deloitte Development LLC, 2010). By valuing diversity and inclusiveness, managers frame a collective 
identity that welcomes and values stakeholders' (i.e., employees, customers, suppliers, investors, and people from the local or global community) different identities. Research suggests that it is through their patterns of inclusion that managers and leaders can positively influence the relationship between diversity and performance (Nishii \& Mayer, 2009).

Valuing diversity begins by incorporating a diversity statement into the organizational mission statement, and promoting consistent organizational values. For example, Chatman and Spataro (2005) have shown that people with different demographic characteristics behave more cooperatively when the organizational culture emphasizes collectivistic values (i.e., benevolence, tradition, conformity) rather than individualistic values (i.e., power, achievement, hedonism, stimulation, self-direction). Collectivistic values are motivated by serving the interests of others and especially the group as a whole such as understanding, appreciating, and tolerating all people with no regard to their rank. Alternatively, individualistic values are motivated by self-interests, such as possessing social status and prestige, controlling and dominating people and their resources or being considered successful and demonstrating competences based on social standard (Schwartz, 1992). Moreover, based on their study, Chatman and Spataro (2005) suggest that when organizational culture emphasizes collectivistic values and interchangeable interests (Chatman, Polzer, Barsade, \& Neale, 1998), people are more likely to perceive that they share a common identity with different people, and as a result, group performance will increase.

The establishment of organizational mission statements and organizational values that support pro-diversity beliefs has increased in volunteer and not-for-profit organizations, as well as other types of organizations (Childs, 2005). For example, the DiversityBusiness.com has identified fifty Top Organizations for Multicultural Business Opportunities. Table 2 presents the mission statements of the ten first listed companies.

Emphasizing the value of diversity into their mission statement has also become especially common practice in universities (Meacham \& Barrett, 2003). For example, Cornell University has a commitment to diversity that states that:

Cornell is committed to extending its legacy of recruiting a heterogeneous faculty, student body and staff; fostering a climate that doesn't just tolerate differences but treasures them; and providing rich opportunities for learning from those differences. To that end, each of Cornell's constituent assemblies endorsed the Statement on Diversity and Inclusiveness, "Open Doors, Open Hearts, and Open Minds."I

Northeastern Illinois University, recognized as one of the most diversity university in the Midwest of the US, emphasizes the value of diversity into its strategic plan:

Diversity - NEIU values the inclusion of a broad spectrum of students, staff, and faculty in the life of the University. We celebrate and foster global perspectives. We encourage the open and respectful expression of ideas and differences in thoughts, experiences, and opinions. ${ }^{2}$

Making diversity a part of the organizational mission statement increases the likelihood that stakeholders will themselves embrace diversity. When the stakeholder's pro-diversity beliefs are aggregated, they become an important component of an organizational climate for diversity (Pugh, Dietz, Brief \& Wiley, 2008). Moreover, research suggests that when stakeholders are committed to embracing diversity, their commitment enhances the likelihood to increase the perform of diverse groups (c.f. van Dick, et al., 2008; van Knippenberg, De Dreu, \& Homan, 2004).

\footnotetext{
${ }^{1}$ http://www.cornell.edu/diversity/

2 http://strategicplan.neiu.edu/diversity_NEIU.html 


\begin{tabular}{|c|c|c|}
\hline Company Name & Source & Diversity Statement \\
\hline 1. Dell & $\begin{array}{l}\text { http://content.dell.com/us/en/corp/d/corp- } \\
\underline{\text { comm/commitment.aspx }}\end{array}$ & $\begin{array}{l}\text { "Diversity is at the core of Dell's values and winning culture. It helps define } \\
\text { the kind of company we are and aspire to be. Diversity initiatives tap } \\
\text { additional talent, retain employees, strengthen relationships, improve our } \\
\text { operating results and further our global citizenship efforts in the many } \\
\text { communities we call home. Dell defines diversity in its broadest sense." }\end{array}$ \\
\hline 2. AT \& T Inc. & http://www.att.com/gen/corporate-citizenship?pid=7752 & $\begin{array}{l}\text { "Diversity is what we do and who we are. AT\&T realizes that diverse, talented } \\
\text { and dedicated people are key to a company's success. The company's } \\
\text { philosophy is to provide employees with continued opportunities to grow and } \\
\text { develop their careers. Management is charged with successful implementation } \\
\text { of various diversity initiatives as part of this philosophy. AT\&T leaders are } \\
\text { expected to understand the importance of cultural competency." }\end{array}$ \\
\hline 3. The Coca-Cola Company & $\begin{array}{l}\text { http://www.thecoca- } \\
\text { colacompany.com/citizenship/diversity.html }\end{array}$ & $\begin{array}{l}\text { "The Coca-Cola Company is a model employer for diversity and inclusion } \\
\text { within its own work force and as a member of the larger business community. } \\
\text { Its leadership on lesbian, gay, bisexual and transgender equality in the } \\
\text { workplace is not only reflected in its long-standing achievement of } 100 \text { percent } \\
\text { on the Corporate Equality Index, but in its principled support of anti- } \\
\text { discrimination legislation that would protect every worker in the United States } \\
\text { from being judged on the basis of their sexual orientation or gender identity." }\end{array}$ \\
\hline 4. Wal-Mart Stores, Inc. & http://walmartstores.com/Diversity/ & $\begin{array}{l}\text { "We make diversity part of our business plan, ensuring we can continue to be a } \\
\text { global leader in all aspects of Diversity and Inclusion." }\end{array}$ \\
\hline 5. Office Depot Inc. & $\begin{array}{l}\text { http://www.officedepot.com/specialLinks.do;jsessionid=00 } \\
\text { 00MgV8tI6n- } \\
\text { BaLaCc8KXqVxVm:13ddpq5n2?file=/companyinfo/comp } \\
\text { anyfacts/diversitymissionstatement.jsp\&template }=\text { compan } \\
\underline{\text { yInfo }}\end{array}$ & $\begin{array}{l}\text { "At Office Depot, we are committed to creating an inclusive environment } \\
\text { where all people are valued and respected. Diversity is an important dimension } \\
\text { of Inclusion, Innovation, and Customer Focus -- three of our core values -- and } \\
\text { keys to our success in a global marketplace." }\end{array}$ \\
\hline 6. Raytheon Company & http://www.raytheon.com/diversity/ & $\begin{array}{l}\text { "Diversity at Raytheon is about inclusiveness - providing an atmosphere } \\
\text { where everyone feels valued and empowered to perform at a peak level, } \\
\text { regardless of the many ways people are different, including but not limited to } \\
\text { age, race, gender, sexual orientation, family history or physical ability." }\end{array}$ \\
\hline $\begin{array}{l}\text { 7. Time Warner Inc./ Turner } \\
\text { Broadcasting System, } \\
\text { Inc. }\end{array}$ & http://www.turner.com/about/diversity.html & $\begin{array}{l}\text { "Turner Broadcasting's commitment to fairness and inclusion is reflected in } \\
\text { the fundamental components of our success. We strive for a professional } \\
\text { environment that values divergent voices, encourages innovative thinking and } \\
\text { expression and rewards individual and collective accomplishment. Our global } \\
\text { workforce of men and women with wide-ranging interests and experience is } \\
\text { empowered by leaders who respect diversity as a business advantage." }\end{array}$ \\
\hline
\end{tabular}




\begin{tabular}{|l|l|l|}
\hline Company Name & \multicolumn{1}{|c|}{ Source } & \multicolumn{1}{|c|}{ Diversity Statement } \\
\hline 8. Lockheed Martin & $\underline{\text { http://www.lockheedmartin.com/aboutus/diversity/diversit }}$ & $\begin{array}{l}\text { "We are committed to creating one company, one team, all-inclusive, where } \\
\text { diversity contributes to the Lockheed Martin vision. Diversity at Lockheed } \\
\text { Martin is an inclusive team that values and leverages each person's } \\
\text { individuality. It's about living our values of doing what's right, respecting } \\
\text { others and performing with excellence. We recognize that our success depends } \\
\text { on the talent, skills and expertise of our people and our ability to function as an } \\
\text { integrated team." }\end{array}$ \\
\hline 9. Cisco Systems, Inc. & $\underline{\text { http://www.cisco.com/web/about/ac49/ac55/index.html }}$ & $\begin{array}{l}\text { "Our inclusive culture promotes a creative, innovative, and collaborative } \\
\text { environment that helps fuel our globalization strategy." "Who you are shapes } \\
\text { who we are: Cisco's employees not only come from different countries, but } \\
\text { also have different backgrounds, genders, ages, ethnicities, and abilities. In } \\
\text { fact, each of us has our own unique approach to life." }\end{array}$ \\
\hline 10. Verizon & $\underline{\text { http://newscenter.verizon.com/kit/diversity/business.html }}$ & $\begin{array}{l}\text { "At Verizon, Diversity means embracing differences and variety including age, } \\
\text { ethnicity, education, sexual orientation, work style, race, gender and more. } \\
\text { When diversity is a part of a company's culture, as it is at Verizon, everyone } \\
\text { benefits - customers, suppliers and employees. Diversity isn't just a concept at } \\
\text { Verizon. It's an integral part of our business." }\end{array}$ \\
\hline
\end{tabular}


To use symbolic management effectively and influence people's positive beliefs in valuing diversity, it is crucial to provide to the stakeholders clear explanations about the reasons why valuing diversity is important to the organization (Sitkin \& Bies, 1993). One way to present this information to the stakeholders is via the organizational mission statement or in organizational reports. For example, Gandz (2001) reminds us that in an era of critical skills shortages, organizations are finding that they must attract, retain, motivate and utilize their valuable human assets effectively if they are to be competitive. Diversity management can reduce turnover, absenteeism and be a powerful magnet in recruitment. Moreover, anticipating and responding to customer needs and being able to maintain a good relationship with suppliers located all around the world remains a priority. Indeed, as pointed out by Gandz (2001), "whether buying fashions in China, beef in Argentina, or machine tools in Germany, the ability to deal with suppliers in their own language, in appropriate behavioral manners, and to conduct successful negotiations may be critical dimensions of competitive advantage". From a globalization perspective, Gandz recognizes that today's "businesses are created through partnerships, joint ventures and strategic alliances. This ability to relate to other cultures becomes a key organizational requirement. It is almost inconceivable today to imagine organizations seeking to become global players without achieving high levels of diversity in their workforces". There is also the motivation of maintaining the image of a good corporate citizen that may influence the importance of valuing diversity. "There are both tangible and intangible benefits and costs associated with being a good corporate citizen and an organization's performance in developing a diverse workforce is one key element in obtaining such a profile". Reducing legal cost is another reason: "The United States and often other countries have to face the very real possibility of legal pressure and sanctions for non-compliance to jurisdictions. Finally, and none the least, managing diversity efficiently may rely on moral principle". Legality and competitive advantage are, however, not the ultimate reasons why diversity should be promoted in organizations.

In summary, using symbolic management may reduce the likelihood for diverse organizations to lead to negative consequences by framing to stakeholders a collective identity, as well as by identifying common goals and values related to believing in diversity. Moreover, by providing clear explanations about the reasons why shareholders should believe in valuing diversity, symbolic management may enhances the likelihood for diverse organizations to increase their performance. By learning to value diversity, over time, stakeholders may incorporate this value into their own personal beliefs which will then reduce biases due to stereotyping and categorization and increase the occurrence of a psychological safety climate (Ho, 2010; Roberge \& Van Dick). Thus, using symbolic management to value diversity is a powerful managerial tool that facilitates the achievement of organizational success in diverse organizations.

\section{Implementing Training Programs And Activities}

Implementing diversity training programs in business and governmental organizations has become a popular strategy, ever since Laws, such as The Civil Rights Act of 1964 and the American Disability Act (ADA) of 1990 passed in the United States, have encouraged the integration of diverse people in the workplace (Naff \& Kellough, 2003; Roberson, Kulik, \& Pepper, 2003). Often diversity trainings in organizations are delivered thought the usage of software such the one offer by Velsoftcourseware.com. ${ }^{3}$

Despite its popularity, researchers have only recently begun examining the impact of such diversity training programs. For example, Peterson and Quarstein (2001) examine the effects of the disability sensitive training conducted at the Virginia School of the Deaf and Blind in Hampton, Virginia, USA. According to their findings, all participants reported that the diversity training program helped them to gain in sensitivity and disability awareness, and each participant left the training with a positive attitude and a new vision of how they might better meet the needs of their student population. Another example is a study conducted by Spanierman, Neville, Liao, Hammer, \& Wang (2008) that explores whether diversity training can successfully become an intervention to meet the organizational challenges face by a culturally diverse student population. The participation in formal campus diversity experiences throughout the first year of college was associated with higher levels of openness to diversity. Moreover, participation in formal diversity experiences also mediated the link between entrance attitudes and beliefs toward different minority groups and follow-up racial color-blind ideology among White, Black, and Latino students. Participation in formal diversity experiences is also important for White, Black, and Latino students in

\footnotetext{
${ }^{3}$ https://velsoftcourseware.com/diversity-training-celebrating-diversity-in-the-workplace/ 
predicting critical awareness of racial issues and diversity appreciation, whereas informal diversity training was important only for Whites in predicting these outcomes. Thus, implementing diversity training programs is now a common and valuable practice used to address the challenges brought by a diverse workforce. Research suggests that implementing diversity training programs may provide to employees the opportunities to acquire the necessary, awareness, knowledge, skills, and abilities to overcome diversity-related conflicts and therefore increase individual and group performance (Plummer, 1998).

Diversity training programs are part of a vast portfolio of training activities perform by most leading organizations. (Pendry, Driscoll, \& Field, 2007). In the following section, we will describe three different forms of formal training programs that are specifically effective for dealing with a diverse workforce: (1) Socialization programs, (2) Cross-training programs, and (3) Team building programs.

Socialization program is defined as the process by which an individual acquires the attitudes, behaviors, and knowledge needed to participate as an organizational member (Ashforth \& Saks, 1996; Van Maanen \& Schein, 1979). Socialization programs are usually offered to the new employees, at the beginning of their employment term. The goal of this kind of program is to help the new employees become familiar with the values, norms, policies and procedures of the organization. This type of program also helps the new employee understand how the organization defines its identity (mission, vision, values, etc). In a socialization process, the employer's role is to frame the organizational identity in such a way that the new employees can feel welcome, enthusiastic and proud of becoming a member of the organization. An example, of such type of training program was implemented by the National Academy of Engineering's Committee on Diversity in the Engineering Workforce in October 2001 (Layne, 2002).

Bauer, Morrison and Callister (1998) identified several reasons why organizations should consider implementing formal socialization training programs. First, it helps the organization transmit and maintain its organizational culture, thus resulting in considerable saving for the organization because employees learn at the outset what is expected of them, and can act in ways that are consistent with the organization's core values and beliefs. Second, it helps organizations retain valuable employees, and, over time, it may positively impact employees' organizational commitment, job satisfaction, and behavioral performance.

Research on diversity suggests that in order to increase employees' pro-diversity beliefs and the likelihood to create a positive organizational climate for diversity, the appropriate policies and practices must be promoted early in the employment term (Gelfand, Nishii, Raver, \& Schneider, 2005). Indeed, these policies and practices must be implemented and conveyed from the beginning of the employment term, during a socialization training program, in order to observe the return that a diverse workforce can bring to the organization. During a socialization training program, the employer must emphasize its beliefs in valuing a diverse workforce and creating a workplace that promote equal employment opportunity to everyone. This informs newcomers about the organization's values and norms related to creating employee perceptions that the organization implements fair policies and practices that seek to create a psychologically safe climate for the firm's stakeholders. McMillan-Capehart (2005) suggests that socialization training programs should result in mutual respect, empathy and trust for one another and acknowledgement of the benefits associated with workforce diversity. It should also prevent employees from stereotyping and getting involved in the categorization process. When people feel welcome and accepted for being who they are, and believe that everyone from this organization is valued equally from the beginning of their employment, employees' perceptions of justice become salient and over time those perceptions created by the socialization process may provide an enormous return in investment for diverse organizations (Lind, 1998). Studies have shown how likely individual productivity and organizational performance will increase when employees' perceive fairness (Simons \& Roberson, 2003). Considering all of the above reasons, it is important to implement socialization programs in diverse organizations, particularly as these programs may lead to an increased in individual and work group, and organizational performance. These programs can be offered by the company itself, or independently by consulting and training organizations (Plummer, 1998). For example, the EADA Management Institute in Finland offers a 2-day program on 'diversity management and intercultural communications:

The aim of the program is to strengthen one's abilities to work and operate in a multicultural environment.... The overall focus of the program is not only on nationalities and cultures but on the diversity of people and international networks in working life. This is done with background and reading material, a personal written learning 
assignment, the 2-day seminar in Finland and a week's education program in Barcelona.....the main focus is on interpersonal communication in order to both show diversity potential, and provide tools for action. ${ }^{4}$

Cross-training program is another type of training that we believe may have value for managers who deal with a diverse workforce. The purpose of cross-training is to broaden trainees' exposure to, and practice on, other teammates' tasks, roles and responsibilities (Day, Gronn, \& Salas, 2004). Cross-training is a concrete example of the expression "put yourself in someone else's shoes". Implementing this type of training in a multifunctional environment can be extremely useful to decrease employees' biases caused by the perceptions of being different based on educational or professional backgrounds, or based on holding a different hierarchical status. Cross training programs help members to better understand one another and their respective function within the team. It is known by research from social psychology that valuing empathy and perspective taking within a team reduces stereotypic biases (Galinsky \& Moskowitz, 2000). Research also shows that cross-training programs in which job are rotated among employees enhance the development of shared team-interaction models (Marks, Sabella, Burke, \& Zaccaro, 2002). Moreover, research specifies that implementing such type of training programs may positively impact organizational performance especially when the team members work on interdependent or complex tasks (Jehn, Northcraft, \& Neale, 1999; Mitchell \& Silver, 1990; Pelled, Eisenhardt, \& Xin, 1999).

There are two different types of cross-training. First, in direct cross-training, the employees execute other group members' jobs for a short period of time (i.e., few hours, a day or possibly a week); in indirect cross-training, the group member observes someone else doing while he/she is performing his/her job.

Numerous training programs that feature cross-training are available. For example, a training organization in the pharmaceutical industry is promoting a report, Managing Cross-Functional Teams for Pharmaceutical Product Commercial Excellence, that summarizes the best practices for developing and utilizing cross-functional teams in new product launch initiatives ${ }^{5}$. Similarly, an online training organization promotes a process for improving the process of selecting cross-functional team members, including mechanisms for identifying team members, team leaders and assuring team success, and clearly specifies diversity criteria. ${ }^{6}$

Team Building. Implementing team building activities has become increasingly popular in organizations. The purpose of such activities is to establish trust and communication among different people. Team building activities help employees to become acquainted with one another on a personal level. Conducting these types of activities at the beginning of an employment term may increase the likelihood for collaborative relationships among group members and the success of future work team assignments. Furthermore, conducting the activity outside the work environment can increase the efficiency of such an activity because it removes the performance anxiety that some employees may experience when they are in a traditional working environment.

For example, Adventure Education is a team building activity program oriented toward identifying the strengths and weaknesses of individuals who participate in these groups. It creates opportunities for groups, and individuals within the groups, to resolve conflicts and communication issues and diminish stress. This experiential learning helps individuals to become more familiar with the concepts of competition and collaboration, and reinforces the value they place on respect for themselves and others (Attarian, 2001). The new knowledge they gain via this experiential learning can be utilized in the work environment as well as in the extended community.

In order for a training program to be effective, many pedagogical techniques must be implemented during the training program. It is not enough to only teach the theoretical concepts related to diversity. Investing money in a diversity training program that will only emphasize "book knowledge" is a waste of time and money. While knowledge is important, it alone will not make people better employees in diverse environment; much experiential and discussion work is required. Making the effort to perceive the world from another's perspective, for example, increases empathy and understanding of others' viewpoints. Employees can be encouraged to do so via job rotation programs (Baxter, 2001). It also leads to more tolerance and acceptance among different individuals. For example,

\footnotetext{
${ }^{4}$ http://www.cec.jyu.fi/avance/koulutusohjelmat/dm/

5 http://www3.best-in-class.com/bestp/domrep.nsf/Content/E1D6C99F92FB4148852572C7006CFDFD!OpenDocument

6 http://www.training-classes.com/programs/00/33/3324_cross-functional_teams_selecting_cross_functional_team_membe.php 
conducting role plays and scenarios during a diversity training program can be an especially useful technique to increase awareness of challenges faced by people living with differences. Role plays may be used to develop the necessary skills needed for individuals to successfully resolve conflicts that may occur among those holding opposing beliefs or interests. In summary, these training techniques might be relevant to increase people's awareness of the issues related to diversity, but especially to help them find solutions that allow potential diversity related conflicts to be resolved.

\section{Implementing Cross-Functional Groups}

Cross-functional groups in the workplace usually take the form of multidisciplinary teams in which each individual is from a different functional area (i.e., production, information systems, marketing, finance, and human resources), or has a different educational or professional background. When the group is composed of individuals from different disciplines or backgrounds, it is defined as being cross-functionally diverse. Research suggests that cross-functional teams are more likely to experience task conflicts. Task conflict exists when there are disagreements among group members about the content of the tasks being performed, including differences in viewpoints, ideas, and opinions (Jehn, 1995). Studies that focus on task conflict within groups have found that such types of conflicts have a positive effect on performance. While this suggests that when people bring their different levels of expertise together, the number of conflicts regarding how to understand or execute a task increases, group performance can ultimately improve. But it is critical to note that research suggests that task conflict can increase group performance in multi-disciplinary groups when it is free of socio-emotional conflicts (i.e., socio-emotional conflicts are relationship-focused and refer to emotional tensions and negative feelings among group members). Managers need to be aware of this aspect when they manage multifunctional teams because studies have often found a positive relationship between task conflict and socio-emotional conflict in the multidisciplinary group (Jehn, 1995).

Gebert, Boerner, and Kearney (2006) have proposed a conceptual model of cross-functionality that can helps managers to understand the role of effective conflicts management. Their primary mechanism is called "synergistic communication", which mediates the relationship between functional/informational diversity and team innovation. Synergistic communication is defined as the extent to which members' divergent positions are specified and recombined to generate new and useful solutions (Gebert, Boerner, \& Kearney, 2006). Their model suggests that the innovativeness of a new product development team is a function of synergistic communication, which is influenced by the types of conflicts that arise in that cross-functional team. Basically, the model assumes that crossfunctionality engenders interpretive differences that increase task conflict, which in turn serves as a catalyst for synergistic communication. However, task conflicts, closely related to socio-emotional conflicts and value conflicts, impede the members' acceptance of divergent ideas and thus obstruct synergistic communication in the team. Moreover, the model identifies three variables that may determine the conditions under which synergistic communication is more likely to occur when expertise diversity exists: (1) common social identity, (2) regard for personal identity and (3) a generalist perspective. A generalist perspective suggests that in order to increase the likelihood of synergistic communication among team members with different expertise, it is vital to let each team member become acquainted with other thought worlds and knowledge, for instance by introducing job rotation programs (Maruyama, 2004).

By identifying these mediators and moderators, this integrative model helps identify the circumstances and explain the mechanisms that may demonstrate how cross-functionality increases group performance.

\section{Stimulating Communication Flow}

As we just mentioned, communication can serve as tool for enhancing group and organizational performance. Communication plays an important and complex role in the psychological composition of the group. Indeed, too many conversations or not enough of them may lead to poor group performance, whereas an adequate amount communication can be very beneficial to the team performance, especially when the quality of the communication is high. 
Furthermore, the outcome of communication can be observed at the individual or the group level. At an individual level, research reports that positive outcomes in diverse environments are associated with self-disclosure (Phillips, Rothbard, \& Dumas, 2009). For example, as pointed out by Ragins, Singh, \& Cornwell (2007), the literature on sexual orientation suggests that disclosure of a gay identity at work may be associated with a sense of psychological wholeness and well-being (Reynolds \& Hanjorgiris, 2000) and may provide relief from the debilitating strain of secrecy involved with leading a double life (Fassinger, 1995; Griffin, 1992). In the domain of mental and physical disabilities, self-disclosing psychological or physical limitations due to a disability may help the employer to provide adequate accommodations that serve the needs of these individuals living with disability (for a review see Ball, Monaco, Schmeling, Schartz, \& Blanck, 2005). Thus, as pointed out by the Personalization Model in diversity management (Ensari \& Miller, 2006), when the context allows employees to learn about each others' personal lives and identity, they have a chance not only to discover similarities between themselves and others, but also to develop mutual understanding of differences that increase the likelihood for a diversity climate to sustain.

Communication can also be at a group level. For example, communication within the organization may be stimulated via social events or by celebrating diversity within the organization. The celebration of diversity may take different forms such as dedicating a specific day of the year to celebrate multiculturalism and differences, or it could be a series of events (i.e., conferences, movie projections, panel discussions, and kiosk activity) organize to celebrate and provide relevant information about critical holidays from a multicultural society such as Chinese New Year, Hanukah, Christmas, Women's Day, Martin Luther King Jr.'s Day, etc. During these events, employees have the opportunity to increase their knowledge about others' cultural identity and challenge their stereotypes.

Other practices such as networking, brainstorming, benchmarking, and community involvement activities are examples of positive solutions related to communication and the management of diversity (Litchfield, 2008). Indeed, improving flow of communication within work units, departments or any other group inside or outside of the organization may be essential for the organization to adapt to the new diversity reality.

United Nations Educational Scientific and Cultural Organization (UNESCO) is an example of organization that practices an open group communication with different cultures. The UNESCO Universal Declaration on Cultural Diversity sets out to respond to two major concerns: firstly, to ensure respect for cultural identities with the participation of all peoples in a democratic framework and, secondly, to contribute to the emergence of a favorable climate for the creativity of all, thereby making culture a factor of development (UNESCO, 2002).UNESCO's activities in communication and information worldwide vary by region and country (UNESCO, 2010)

\section{Promoting Fairness In Human Resource Practices}

It has been widely recognized that effective diversity management can be achieved through using appropriate human resource policies and practices (Dass, \& Parker, 1999; Shen, Chanda, D’Netto \& Monga, 2009). A growing number of organizations have already enacted sexual harassment policies, and implemented policies that prohibit discrimination based on gender, race, ethnicity, religion, sexual orientation or disabilities. Implementing such policies in organizations becomes strength to prevent and resolve diversity related conflicts. For example, research on sexual diversity has demonstrated that the more prevalent these policies are, the less likely sexual minority members are to experience discriminatory treatment (Ragins, \& Cornwell, 2001). Furthermore, Button's study (2001) shows that more equitable treatment was associated with higher levels of satisfaction and commitment among lesbian and gay employees. Thus, overall, research has suggested that when organizational strategy and HR policies and practices support diversity initiatives, diversity is more likely to lead to positive performance outcomes (Kochan, Bezrukova, Ely, Jackson, Joshi, Jehn, Leonard, Levine and Thomas, 2003).

Implementing fair policies, procedures and practices is a critical characteristic of a working environment that embraces the integration of diverse employees (Chuang, Church, \& Zikic, 2004; Hicks-Clarke \& Iles, 2000; McKay, et al., 2008; Mor Barak, Cherin, \& Berkman, 1998; Morbarak, Findler, \& Wind, 2003). Because of their perceived differences and related uncertain feelings, employees in diverse organizations are likely to become sensitive to issues related to fairness and trust (van den Boss, 2001). Therefore, it is by emphasizing fair treatment that managers will be able to lessen the level of group conflict in diverse organizations. When different group members share perceptions of justice, research suggests that it becomes easier for them to work together. Justice 
climate is therefore considered an important moderator of the relationship between diversity, group processes and group performance (Roberson \& Colquitt, 2005).

The process of fair treatment in the workplace is well represented by the literatures on distributive justice (i.e., fairness of the outcomes) (Adams, 1965) and procedural justice (i.e., fairness of the procedures that lead to determine those outcomes) (Leventhal, 1980), and interactional justice (Bies, \& Moag, 1986). Research suggests that when employees perceive that the organization violates distributive, procedural justice or interactional justice, they are more likely to have paranoiac reactions to a diversity workforce (Kramer, 2001).

Managing justice in diverse organizations is a very complex process because it requires a certain level of standardization and at the same time it requires some flexibility. For example, in order to embrace diversity and respond to it appropriately, organizations must offer reasonable accommodations to working parents (Shina, Wong, Simlo, \& Ortiz-Torres, 1989), people living with disabilities (Steinberg, Iezzoni, Conill, \& Stineman, 2002) or people believing in different religions (Cash, \& Gray, 2000). Therefore, establishing idiosyncratic deals in a diverse organization may become an appropriate practice in order to enhance fairness perception. Recent research suggests that establishing idiosyncratic deal (i. e., personalized employment arrangements negotiated between individual workers and employers and intended to benefit them both) may indeed increase perception of justice from the eye of the receiver. However, such type of idiosyncratic deal may also increase group members' suspicious and perceptions of unfair treatment unless they believe that comparable opportunity will be offered to them in the future (Greenberg, Roberge, Ho, \& Rousseau, 2005; Lai, Rousseau, \& Chang, 2009). This area of research about ideals is brand new to the literature; more research is definitely needed in order to further understand the role of i-deals in accommodating people who have with special needs and therefore better respond to a diverse workforce.

To be perceived as a fair organization, diverse organizations must align their human resource functions (i.e., recruitment, selection, performance appraisal and allocation of promotion, compensation etc.) toward the implementation of supportive diversity practices. In the next sections, we will briefly review the literature that addresses supportive diversity practices during three the recruitment process, the selection process and the performance evaluation process.

Recruitment. To conduct a recruitment process that will be perceived as fair, organizations should encourage everyone, including candidates from minority groups to apply on the opening positions. Research suggests that in order to be successful at recruiting a diverse pool of applicants, organizations must convey commitment toward valuing diversity early during the recruitment process (Avery \& McKay, 2006; Highhouse, Stierwalt, Bachiochi, Elder, \& Fisher, 1999; Kim \& Gelfand, 2003; Thomas \& Wise, 1999). For example, portraying photographs of people with different race, ethnicity, gender, age, or abilities in recruitment advertisements is now becoming a popular practice reflected in the overwhelming majority (78\%) of Fortune 100 companies that portray diverse people on their Web sites (Cober, Brown, \& Levy, 2004). Websites such ThinkBeyondtheLabel.com, that promotes hiring people living with disabilities, are becoming popular. Research suggests that minority applicants tend to prefer advertisements that portray diversity rather than advertisements that to not portray it (Avery, 2003; Perkins et al., 2000). Research also suggests that promoting policies of equal opportunity enhances female and minority applicants' positive perceptions of the organization (Highhouse et al, 1999; McNab \& Jognston, 2002; Slaughter, Sinar, \& Bachiochi, 2002). Therefore, implementing advertisements with such characteristics might be fruitful to attract diverse applicants and being perceived as a fair organization early in the recruitment process.

Moreover, research suggests that the extent of discrimination that occurs during the recruiting process depends on the channels that are used to recruit applicants (Gelfand et al., 2005). For example, research suggests that organizations that rely on informal networks to fill open positions may increase the probability of discriminating against group who often do not have equal access to these social networks that are to jobs. Thus, to recruit a diverse pool of applicants, organizations must be proactive in developing partnerships with the community such as school systems, vocational rehabilitation agencies, and minority associations (Heneman, Waldeck, \& Cushnie, 1996). Moreover, it is important for organizations to not only rely on informal networks but also to use a variety of communication media (i.e., newspapers, radio advertisements, Internet websites, etc.) to announce job openings. 
Finally, other research suggests that embracing diversity requires organizations to recruit people with "extended fit" instead of people with "reinforcing fit" (Powell, 1998). Recruiting people that have complementary instead of similar values, knowledge, skills, abilities and other job relevant characteristics is considered a valuable practice for organizations to show efforts toward valuing diversity.

Selection Process. Once the organization has obtained a broad and diverse pool of applicants, it may happen during the selection process that more than one candidate are equally qualified for the position. In order to meet the affirmative action or equal opportunity hiring objectives, some firms may assume that it is appropriate to give preferential treatment to women and racioethnic minorities by hiring and promoting them over qualified white men. Indeed, it has been largely recognized by researchers that affirmative action has often come to be seen by the public as involving preferential selection, often in the form of quotas in hiring (Holloway, 1989; Kravitz \& Platania, 1993; Northcraft \& Martin, 1982). Such practices are illegal and therefore may often be interpreted, especially by Caucasian men, as unfair favoritism and reverse discrimination (Heilman, McCullough, \& Gilbert, 1996). Recruiting a broad and diverse pool of applications and selecting the best candidate based on its capacity to performance the task and responsibilities included in the job description are essential conditions to create a positive climate for diversity in which the perceptions of being fairly treated prevail. Also, to be considered fair, the selection process should rely on valid and reliable selection tools. Extensive research has shown that various selection instruments are discriminatory toward minorities (Arvey \& Landon, 1992; Brown \& Day, 2006). Therefore, as mentioned by Gelfand et al. (2005) "the best way to combat discrimination in selection is to use measures that tap as many aspects of job performance as possible, to utilize different media in terms of the ways in which content is presented and responses are required and to use noncognitive measure such as personality and integrity test when possible" (p. 101).

An example of a hiring practice that is considered fair is Rooney's Rule, used by the National Football League (NFL). This rule was devised to address the issue of the disproportionate number of black coaches compare to black football players in the NFL. Black football players comprised $70 \%$ of the NFL's team, whereas $28 \%$ (assistant coaches) and 6\% (head coaches) were black. Rooney's rule mandates that during the interview process for NFL coaches, an equal number of black and white coaches should have an opportunity to be interviewed; in other words, Ronney proposes that for every white coach interviewed, at least one minority head coach should also be interviewed (Garber, 2007). This practice has now been expanded to the interview process for the position of General Manager (Associated Press, 2009).

Performance Evaluation Process. Existing research on performance appraisal suggests that in order to reduce and eliminate discrimination in the performance evaluation process, organizations must implement performance management systems that involve explicit performance expectations, clear performance criteria, valid and reliable measures, regular performance feedback, and consistent application of these standards across employees (Bernardin, Hagan, Kane \& Villanova, 1998; Gelfand et al., 2005; Klimoski \& Donahue, 1997; Morrison \& Von Glinow, 1990).

Moreover, research drawing on self-verification theory (Swann, Rentfrow, \& Guinn, 2005) suggests that evaluating and rewarding performance should be done at both, an individual level and a group level. According to self-verification theory, it is crucial for each member to be recognized as a group member, but also as a respected for being an individual with unique characteristics. Both "Who am I, as an individual?" and" Who am I, as a group member?" are crucial questions that different people working together must address and mutually confirm in order for them to be able to enhanced group performance. This argument has also been proposed by optimal distinctiveness theory (Brewer, 1991; for review see Brewer, 2003). According to optimal distinctiveness theory, the need for inclusion and the need for differentiation are people's basic needs. Social identity derives from a fundamental tension between the human need for inclusion, validation and similarity to others, whereas personal identity comes from this countervailing need for uniqueness and individuality. Both of these needs must be fulfilled in order to motivate group identification and perception of justice which, in turn, increase group performance. Therefore, according to these two social psychology theories, in order to increase perception of justice in diverse environments which, in turn, will increase group performance, evaluating and rewarding performance (i. e., giving a promotion or a compensation) should be done at both levels, the individual and the group level. Empirical research also shows supportive evidence of such a theoretical argument. For example, Milton and Westphal (2005) found that mutual identity confirmation at both levels (the individual and the group level) mediate the relationship between diversity and cooperation. 


\section{CONCLUSION}

Based on research and theories, from Organizational Behavior, Human Resource Management and Social Psychology, we have identified and discussed five managerial practices that help the employer to manage diverse organizations efficiently. These managerial practices are: (1) Using symbolism management to value diversity, (2) Implementing diversity training programs, (3) Implementing cross-functional teams, (4) Stimulating communication flow, and lastly (5) Promoting fairness and justice in human resource practices.

By specifying and explaining how research and theories can be utilized and applied to understand the complexity of managing a diverse workforce and to propose a combination of strategic managerial practices, this paper contributes to fill the gap that exists between research and practices. As pointed out by Pendry, Driscoll, \& Susannah (2007), "when it comes to strategies for tackling diversity issues, there is something of a divide between theory and practice (p., 27). Thus, while one major contribution of this paper was to recommend, based on research and theory, some valuable managerial practices that increase the success of diverse organizations, another contribution was to provide applied examples of these organizations that successfully implement authentic managerial practices to effectively manage diversity and therefore increase their overall performance.

Today, multinational corporations and other organizations are now planning, implementing, and evaluating a large number and variety of diversity initiatives (Wentling \& Palma-Rivas, 2000). This is positive news that must continue. The examples provided in this paper of organizations that have already committed themselves to valuing diversity must pursue their commitment and hopefully will influence other organizations to adopt the appropriate managerial practices that will lead diversity to increase organizational performance.

Managing diversity effectively is a complex and delicate process that requires the implementations of a combination of diversity practices. It is not enough to only refer to the word "diversity" into the organization's mission statement. Organizations must engage themselves in a long-term commitment toward embracing diversity through the implementation of multiple diversity practices and supportive activities that will enhance the organizational performance. Even though each recommended practices may help managers to deal with diversity more effectively, implementing only one or two of these practices would be insufficient to leverage the full potential of diversity. Research suggests that the full potential of diversity will be released only by implementing a combination of strategic managerial practices that support diversity activities.

\section{ACKNOWLEDGEMENTS}

We are grateful and thankful to Stella Nkomo, Joshi Aparna, Moira Wichman, Hassan R. Baqar, and Tina Gountanis Espin for their comments on a previous version of that paper.

\section{AUTHOR INFORMATION}

Marie-Élène Roberge is an Assistant Professor at Northeastern Illinois University in the College of Business and Management. She earned a Ph.D. from Fisher College of Business at the Ohio State University, majored in Labor and Human Resource Management and a minored in Social Psychology. Her research is about managing diversity in organizations and understanding individual and group behaviors in the workplace. She has published in several journals such as Research in Personnel and Human Resource Management, and Human Resource Management Review. She teaches strategic management, leadership and organizational behavior as well as diversity in organizations. E-mail: M-Roberge@neiu.edu

Roy J. Lewicki is the Abramowitz Professor of Business Ethics, Management and Human Resources at the Max M. Fisher College of Business, The Ohio State University. Prof. Lewicki maintains research and teaching interests in the fields of negotiation and dispute resolution, trust development, managerial leadership, organizational justice and ethical decision making. He is the author of numerous research articles in these fields, as well as an extensive repertoire of teaching materials. His recent books include Negotiation (McGraw Hill/Irwin, 6h Edition 2010) and Making Sense of Intractable Environmental Conflicts: Frames and Cases (Island Press, 2003). E-mail: lewicki.1@osu.edu 
Amy Hietapelto is the dean of College of Business and Management at Northeastern Illinois University. She earned her Ph.D. in Business Administration (Organizational Studies) from the University of Minnesota. Dr. Hietapelto's industry experience includes stints at IBM and Merrill Lynch. Her research focuses on pedagogical, curricular and legal issues in management education, as well as issues in organizational behavior. Dr. Hietapelto teaches strategic management, organizational behavior, leadership, change management, and diversity. She has published in the Journal of Management Education, Journal of Organizational Behavior Management, Journal of University and College Law, and Journal of Legal Studies Education. E-mail: A-Hietapelto@ neiu.edu

Aijana Abdyldaeva graduated in 2003 from Kyrgyz-Russian Slavic University in Bishkek, Kyrgyzstan, earning a Bachelor's degree with a major in Economics. She is currently a graduate student at Northeastern Illinois University, earning her Master's Degree in Business Administration. At the same time, she is also a Graduate Research Assistant, doing research in workforce diversity, leadership and voice behavior. E-mail: abdyldaevaaijana@yahoo.com

\section{REFERENCES}

1. Adams, J. S. (1965). Inequity in social exchange. In L. Berkiwitz (Ed.), Advance in experimental social psychology (Vol. 2, pp. 267-299). New York: Academic Press.

2. Albert, S., \& Whetten, D. (1985). Organizational identity. In L. L. Cummings and B. M. Staw (Eds.), Research in organizational behavior (Vol 7). Greenwich, CT: JAI.

3. $\quad$ Allport, G. H. (1954). The nature of prejudice. Cambridge, MA: Addision-Wesley.

4. Arvey, R. D., \& Landon, T. E. (1992). Development of physical ability test for police officers: A construct validation approach. Journal of Applied Psychology, 77, 996-1009.

5. $\quad$ ASAE and Center for association leadership (2006). http://www.asaecenter.org/PublicationsResources/ANowDetail.cfm?ItemNumber=14735

6. Ashforth, B., \& Saks, A (1996). Socialization tactics: Longitudinal effects on newcomers' adjustment. Academy of Management Journal, 39, 149-178.

7. Associated Press (2009). Owners meetings roundup: NFL may expand 'Rooney Rule' to GM's, http://sportsillustrated.cnn.com/2009/football/nfl/05/20/rooney.ap/index.html

8. Attarian, A. (2001). Trends in outdoor adventure education. Journal of Experimental Education, 24, 14149.

9. Avery D. R. (2003). Reactions to diversity in recruitment advertising —Are differences black and white? Journal of Applied Psychology, 88, 672-679.

10. Avery, D. R., \& McKay, P. F. (2006). Target practice: An organizational impression management approach to attracting minority and female job applicants. Personnel Psychology, 59, 157-187.

11. Ball, Monaco, Schmeling, Schartz, \& Blanck, (2005). Disability as diversity in Fortune 100 companies. Behavioral Science and Law, 23, 97-121.

12. Bauer, T.N., Morrison E. W., \& Callister, R. R. (1998). Organizational socialization: A review and directions for future research. Research in Personnel and Human Resources Management, 16, 149-214.

13. Baxter, C. (2001) Managing Diversity and Inequalities in Health Care. Baillière Tindall http://books.google.com/books?id=uAzQvjP8vSYC\&pg=PA40\&lpg=PA40\&dq=managing+diversity+job+ rotation\&source=bl\&ots=U2Zw049uIM\&sig=tPmylVQo5k1JizGFooOtb6 0qwg\&hl=en\&ei=k0pCSomdO $\underline{Z}$ BtwfYu_yjCQ\&sa=X\&oi=book_result\&ct=result\&resnum $=4$

14. Bernardin, H. J., Hagan, C. M., Kane, J. S., \& Villanova, P. (1998). Effective performance management: A focus on precision, customers, and situational constraints. In J. W. Smither (Ed.), Performance appraisal: State of the art in practices (pp. 3-48). San Francisco: Jossey-Bass.

15. Bies, R. J., \& Moag, J. S. (1986). Interactional justice: Communication criteria of fairness. In R. J. Lewicki, B. H. Sheppard, \& M. H. Bazerman (Eds.), Research on negotiation in organizations (pp. 43-55), Greenwich, CT: JAI Press.

16. Brewer, M. B. (1991). The social self: On being the same and different at the same time. Personality and Social Psychology Bulletin, 17, 475-482.

17. Brewer, M. B. (2003). Optimal distinctiveness, social identity, and the self. In M. R Leary, \& J. P. Tangney (Eds.), Handbook of Self and Identity_(pp. 480-491), The New York: Guilford Press. 
18. Brewer, M. B., \& Brown, R. J. (1998). Intergroup relations. In D. T. Gilbert, S. T. Fiske, G. Lindzey (Eds.), The Handbook of Social Psychology (Vol. 2, pp. 554-594), McGraw-Hill Companies, Inc.

19. Brewer, M. B., \& Gaertner, S. L. (2004). Toward reduction of prejudice intergroup contact and social categorization. In M. B. Brewer \& M. Hewstone (Eds.), Self and Social Identity (pp. 298-318). Malden, MA: Blackwell Publishing.

20. Brown, R. P., \& Day, E. A. (2006). The difference isn't black and white: stereotype threat and race gap on raven's advanced progressive matrices. Journal of Applied Psychology, 91, 979-985.

21. Button, S. B. (2001). Organizational efforts to affirm sexual diversity: A cross-level examination. Journal of Applied Psychology, 86, 17-28.

22. Cash, K. C., \& Gray, G. R. (2000). A framework for accommodating religion and spirituality in the workplace. Academy of Management Executive, 14, 124-134.

23. Chatman, J., Polzer, J., Barsade, S., \& Neale, M. (1998). Being different yet feeling similar: The influence of demographic composition and organizational culture on work processes and outcomes. Administrative Science Quarterly, 43, 749-780.

24. Chatman, J. A., \& Spataro, S. E. (2005). Using self-categorization theory to understand relational demography-based variations in peoples' responsiveness to organizational culture. Academy of Management Journal, 48, 321-331.

25. Childs, J. T. Jr. (2005). Managing workforce diversity at IBM: A global HR topic that has arrived. Human Resource Management, 44, 73-77.

26. Chuang, Y. T., Church, R., \& Zikic, L. (2004). Organizational culture, group diversity and intra-group conflict. Team Performance Management, 10, 26-34.

27. Cober R.T., Brown D. J., Levy P.E. (2004). Form, content, and function: An evaluative methodology for corporate employment web sites. Human Resource Management, 43, 201-218.

28. Cox, T. (1991). The multicultural organization. Academy of Management Executive, 5, 34-47.

29. Cox, T. (1993). Cultural diversity in organizations: theory, research \& practices. San Francisco: BerrettKoehler Publishers.

30. Cox, T., Lobel, S.A., \& McLeod, P.L. (1991). Effects of ethnic group cultural differences on cooperative and competitive behavior on a group task. Academy of Management Journal, 4, 827-847.

31. Dass, P., \& Parker, B. (1999). Strategies for managing human resource diversity: From resistance to learning. Academy of Management Executive, 13, 68-80.

32. Day, D.V., Gronn, P., \& Salas, E. (2004). Leadership capacity in teams. Leadership Quarterly, 15, 857880.

33. Deloitte Development LLC (2010). http://www.deloitte.com/view/en_US/us/About/DiversityInclusion/article/d2015da0ffb05210VgnVCM100000ba42f00aRCRD.htm

34. DiversityBusiness.com (2010). http://www.diversitybusiness.com/news/supplierdiversity/45201056.asp

35. Ely, R., \& Thomas, D. A. (2001). Cultural diversity at work: The effects of diversity perspectives on work group processes and outcomes. Administrative Science Quarterly, 46, 229-273.

36. Ensari, N. K., \& Miller, N. (2006). The application of the personalization model in diversity management. Group Processes and Intergroup relations, 9, 589-607.

37. Fiss, P.C., \& Zajac, E. J. (2006). The symbolic management of strategic change: Sensegiving via framing and decoupling. Academy of Management Journal, 49, 1173-1193.

38. Fassinger, R. E. (1995). From invisibility to integration: Lesbian identity in the workplace. Career Development Quarterly, 44, 148-167.

39. Gaertner, S. L., \& Dovidio, J. F. (2000). Reducing intergroup bias: The common ingroup identity model. Philadelphia: Psychology Press.

40. Gaertner, S. L., Dovidio, J. F., Anastasio, P. A., Bachman, B. A., \& Rust, M. C. (1993). The common ingroup identity model: Recategorization and the reduction of intergroup bias. In W. Stroebe \& M. Hewstone (Eds.), European Review of Social Psychology (Vol. 4, pp. 1-26). London: Wiley.

41. Gaertner, S. L., Dovidio, J. F., Nier, J. A., Ward, C. M., \& Banker, B. S. (1999). Across cultural divides: The value of a superordinate identity. In D. Prentice \& D. Miller (Eds.), Cultural divides: Understanding and overcoming group conflict_(pp. 173-212). New York: Russell Sage Foundation.

42. Galinsky, A.D., \& Moskowitz, G.B. (2000). Perspective-taking: Decreasing stereotype expression, stereotype accessibility, and in-group favoritism. Journal of Personality and Social Psychology, 78, 708724. 
43. Gandz (2001). A Business Case for Diversity. http://www.servicecanada.gc.ca/eng/lp/lo/lswe/we/special_projects/RacismFreeInitiative/BusinessCasee.shtml\#executive\%20summary

44. Garber, G. (2007). Thanks to Rooney Rule, doors opened. http://sports.espn.go.com/nfl/playoffs06/news/story?id=2750645

45. Gärling, T (1999). Value priorities, social value orientations and cooperation in social dilemmas. British Journal of Social Psychology, 38, 397-408.

46. Gebert,D., Boerner, S., \& Kearney, E. (2006). Cross-functionality and innovation in new product development teams: A dilemmatic structure and its consequences for the management of diversity. European Journal of Work and Organizational Psychology, 15, 431-458.

47. Gelfand, M.J., Nishii, L.H., Raver, J., \& Schneider, B. (2005). Discrimination in organizations: An organizational level systems perspective. In R. Dipboye \& A. Colella (Eds.), Discrimination at work: The psychological and organizational bases: 89-116. Mahwah, NJ: Erlbaum.

48. Gonzalez, J. A., \& Denisi, A. S. (2009). Cross-level effects of demography and Diversity climate on organizational attachment and firm effectiveness. Journal of Organizational Behavior, 30, 21-40.

49. Greenberg, J., Roberge, M.E., Ho, V. T., \& Rousseau, D. M. (2005). Fairness as an "i-deal”: Justice in under-the-table employment arrangement. In J. Matocchio (Ed.), Research in Personnel and Human Research Management (Vol. 22, pp. 1-34). San Diego, CA: Elsevier.

50. Griffin, P. (1992). From hiding out to coming out: Empowering lesbian and gay educators. In K. M. Harveck (Ed.), Coming out of the classroom closet: Gay and lesbian students, teachers and curricula (pp. 167-196). Binghampton, NY: Haworth Press.

51. Heilman, M. E., McCullough, W. F., \& Gilbert, D. (1996). The other side of affirmative action: reactions of nonbeneficiaries to sex-based preferential selection. Journal of Applied Psychology, 81, 346-357.

52. Heneman, R. L., Waldeck, N. E., \& Cushnie, M. (1996). Diversity considerations in staffing decisionmaking. In E.E. Lossek \& S. A. Lobel (Eds.), Managing Diversity, (pp. 74-101).

53. Hicks-Clarke, D., \& Iles, P. (2000). Climate for diversity and its effects on career and organizational attitudes and perceptions. Personnel Review, 29, 324-345.

54. Highhouse, S., Stierwalt, S. L., Bachiochi, P., Elder, A. E., \& Fisher, G. (1999). Effects of advertised human resource management practices on attraction of African American applicants. Personnel Psychology, 52, 425-442.

55. Ho, C. (2006). Does heterogeneity inspire team psychological safety? Paper presented at the Academy of Management Conference, Atlanta, GA, USA.

56. Hobman, E. V., Bordia, P., \& Gallois, C. (2004). Perceived dissimilarity and work group involvement. Group and Organization Management, 29, 560-587.

57. Holloway, F. (1989). What is affirmative action? In E Blanchard \& E Crosby (Eds.), Affirmative action in perspective (pp.9-19). New York: Springer-Verlag.

58. Hyde, C. A., \& Hopkins, K. (2004). Diversity climates in human service agencies: An exploratory assessment. Journal of Ethnic \& Cultural Diversity in Social Work, 13, 25-43.

59. Jackson, S. E. (1992). Consequences of group composition for the interpersonal dynamics of strategic issue processing. Advances in Strategic Management, 8, 345-382.

60. James, E. H., \& Wooten, L. P. (2006). Diversity crises: How firms manage discrimination lawsuits. Academy of Management Journal, 49, 1103-1118.

61. Jamieson, D. \& O’Mara, J. (1991). Managing Workforce 2000: Gaining the Diversity Advantage. JosseyBass Publishers.

62. Janis, I. (1982). Groupthink ( ${ }^{\text {nd }}$ Ed.), Boston: Houghton-Mifflin.

63. Jehn, K. (1995). A multimethod examination of benefits and detriments of intragroup conflict. Administrative Science Quarterly, 40, 256-282.

64. Jehn, K. A., Northcraft, G. B., \& Neale, M. A. (1999). Why differences make a difference: A field study of diversity, conflict, and performance in workgroups. Administrative Science Quarterly, 44, 741-763.

65. Kim, S. S. \& Gelfand, M. J. (2003). The influence of ethnic identity on perceptions of organizational recruitment. Journal of Vocational Behavior, 63, 396, 416.

66. Kirby, S. L., \& Richard, O. C. (1996). An investigation of workforce diversity programs: A multiple perspective approach. Equal Opportunities International, 15, 17-27. 
67. Klimoski, R. \& Donahue, L. (1997). HR Strategies for integrating individuals with disabilities into the workplace. Human Resource Management Review, 7, 109-138.

68. Kochan, T., Bezrukova, K., Ely, R., Jackson, S., Joshi, A., Jehn, K., Leonard, J., Levine, D., and Thomas, D. (2003). The effects of diversity on business performance. Report of the diversity research network. Human Resource Management, 42, 3-21.

69. Kramer, R. M. (2001a). Organizational paranoia origins and dynamics. Research in Organizational Behavior, 23, 1-42.

70. Kravitz, D., \& Platania, J. (1993 ). Attitudes and beliefs about affirmative action: Effects of target and or respondent sex and ethnicity. Journal of Applied Psychology, 78, 928-938.

71. Lai, L., Rousseau, D. M., Chnag, K. T. T. (2009). Idiosyncratic deals: Coworkers as interested third parties. Journal of Applied Psychology, 94, 547-556.

72. Layne, P. (2002). Best practices in managing diversity. Leadership and Management in Engineering, 2, 2830.

73. Leventhal, G. S. (1980). What should be done with equity theory? In K. J. Gergen, M. S. Greenberg, \& R. H. Willis (Eds.), Social exchange: Advance in theory and research (pp. 27-55). New York: Plenum.

74. Lind, A. (1998). Fairness heuristic Theory: Justice judgments as pivotal cognitions in organizational relations. In J. Greenberg, \& R. Cropanzano (Eds.), Advances in Organizational Justice. Stanford University Press.

75. Litchfield, R. C. (2008). Brainstorming reconsidered: A Goal-based view. Academy of Management Review, 33, 649-669.

76. Marks, M.A., Sabella, M.J., Bruke, C.S., \& Zaccaro, S.J. (2002). The impact of cross-training on team effectiveness. Journal of Applied Psychology, 87, 3-13

77. Maruyama, M. (2004). Polyocular vision or subunderstanding? Organization Studies, 25, 467-480.

78. McKay, P.F., Avery, D.R., \& Morris, M. A. (2008). Mean racial-ethnic differences in employee sales performance: The moderating role of diversity climate. Personnel Psychology, 61, 349-374.

79. McKay, P. F., Avery, D. R., \& Morris, M. A. (2009). A tale of two climates: Diversity climate from subordinates' and managers' perspectives and their role in store unit sales performance. Personnel Psychology, 62, 767-791.

80. McMillan-Capehart, A. (2005). A configurational framework for diversity: Socialization and culture. Personnel Review, 34, 488-503.

81. Meacham, J. \& Barrett, C. (2003). Commitment to diversity in institutional mission statements. Diversity, Digest, 7, (http://www.diversityweb.org/digest/vol7no1-2/meacham-barrett.cfm)

82. Mitchell, T. E., \& Silver, W. S. (1990). Individual and group goals when workers are interdependent effects on task strategies and performance. Journal of Applied Psychology, 75, 185-193.

83. Milton, L. P., \& Westphal, J. D. (2005). Identity confirmation networks and cooperation in groups. Academy of Management Journal, 48, 191-212.

84. Mor Barak, M.E. (2000). The inclusive workplace: An ecosystems approach to diversity management. Social Work, 45, 339-352.

85. Mor Barak, M.E., Cherin, D. A., \& Berkman, S. (1998). Organizational and personal dimension in diversity climate: Ethnic and gender differences in employee perceptions. Journal of Applied Behavioral Science, 34, 82-104.

86. Morbarak, M. Findler, L., \& Wind, L. (2003). Cross-cultural aspects of diversity and well-being in the workplace. An international perspective. Journal of Social Work Research and Evaluation, 4, (2), 49-73.

87. Morrison, A. M., \& Von Glinow, M. A. (1990). Women and minorities in management. American Psychologist, 45, 200-208.

88. Naff, K. \& Kellough, E. 2003. Ensuring employment equity: Are federal diversity programs making a difference? International Journal of Public Administration, 26: 1307-1336.

89. Nishii, L. H., \& Mayer, D. M. (2009). Do inclusive leaders help to reduce turnover in diverse groups? The moderating role of leader-member exchange in the diversity to turnover relationship. Journal of Applied Psychology, 94, 1412-1426.

90. Northcraft, G. B., \& Martin, J. (1982). Double jeopardy: Resistance to affirmative action from potential beneficiaries. In B. Gutek (Ed.), Sex role stereotyping and affirmative action policy (pp. 81-130). Los Angeles: Institute of Industrial Relations, University of California. 
91. Pendry, L. F., Driscoll, D. M., \& Field, S. C. T. (2007). Diversity training: Putting theory into practice. Journal of Occupational and Organizational Psychology, 80, 27-50.

92. Pelled, L. H., Eisenhardt, K. M., \& Xin, K. R. (1999). Exploring the black box: An analysis of work group diversity, conflict, and performance. Administrative Science Quarterly, 44, 1-28.

93. Perkins, L. A., Thomas, K. M., \& Taylor, G. A. (2000). Advertising and recruitment: Marketing to minorities. Psychology \& Marketing, 17, 235-255.

94. Peterson, P.A., \& Quarstein, V. A. (2001). Disability awareness training for disability professionals. Disability and Rehabilitation, 23, 43-48.

95. Phillips, K. W., Rothbard, N. P., \& Dumas, T. L. (2009). To disclose or not to disclose? Status distance and self-disclosure in diverse environments. Academy of Management Review, 34, 710-732.

96. Ployhart, R. E. (2006). Staffing in the $21^{\text {st }}$ century: New challenges and strategic opportunities. Journal of Management, 32, 868-897.

97. Plummer, D. L., (1998). Approaching diversity training in the year 2000. Consulting Psychology Journal: Practice and Research, 50, 181-189.

98. Powell, G. N. (1998). Reinforcing and extending today's organizations: the simultaneous pursuit of personorganization fit and diversity. Organizational Dynamics, 26, 50-61.

99. Pugh, S. D., Dietz, J. Brief, A. P.,\& Wiley, J. W. (2008). Looking inside and out: The impact of employee and community demographic composition on organizational diversity climate, Journal of Applied Psychology, 93, 1422-1428.

100. Pruitt, S. W., \& Nethercutt, L. L. (2002). The Texaco racial discrimination case and shareholder wealth. Journal of Labor Research, 23, 685-694.

101. Ragins, B. R., \& Cornwell, J. M. (2001). Pink triangles: Antecedents and consequences of perceived workplace discrimination against gay and lesbian employees. Journal of Applied Psychology, 86, 12441261.

102. Ragins, B. R., Singh, R., \& Cornwell, J.M. (2007). Making the invisible visible: Fear and disclosure of sexual orientation at work. Journal of Applied Psychology, 92, 4, 1103-1118.

103. Reynolds, A. L., \& Hanjorgiris, W. F. (2000). Coming out: Lesbian, gay, and bisexual identity development. In R. M. Perez, K. A., DeBord \& K. J. Bieschke (Eds.) Handbook of counseling and psychotherapy with lesbian, gay, and bisexual clients (pp. 35-55). Washington, DC: American Psychology Association.

104. Richard, O. C., Kochan, T. A., \& McMillan-Capehart, A. (2002). The impact of visible diversity on organizational effectiveness: Disclosing the contents in pandora's black box. Journal of Business and Management, 8, 265-291.

105. Roberge, M.É. \& Van Dick, R. J. (2010). Recognizing the Benefits of Diversity: When and how does Diversity Increase Group Performance. Human Resource Management Review, 20 (4), pp. 295-308.

106. Roberson, L., Kulik, C.T., Pepper, M. B. (2003). Using needs assessment to resolve controversies in diversity training design. Group \& Organization Management, 28, 148-174.

107. Roberson, Q. M., \& Colquitt, J. A. (2005). Shared and configural justice: A social network model of justice in teams. Academy of Management Review, 30, 595-607.

108. Selmi, M. 2003. The price of discrimination: The nature of class-action employment discrimination litigation and its effects. Texas Law Review, 81: 1249-1335.

109. Shen, J., Chanda, A., D’Netto, B., \& Monga, M. (2009). Managing diversity through human resource management: An international perspective and conceptual framework. The International Journal of Human Resource Management, 20, 235-251.

110. Shinn, M., Wong, N. W., Simko, P. A., \& Ortiz-Torres, B. (1989). Promoting the well-being of working parents: Coping, social support, and flexibility job schedule. American Journal of Community Psychology, 17, 31-55.

111. Shore, L. M., Chung-Herrera, B. G., Dean, M. A., Ehrhart, K.H., Jung, D. I., Randel, A. E., \& Singh, G. (2009). Diversity in organizations: Where are we now and where are we going? Human Resource Management Review, 19, 117-123.

112. Simons, T., \& Roberson, Q. (2003). Why managers should care about fairness: The effects of aggregate justice perceptions on organizational outcomes. Journal of Applied Psychology, 88, 432-443.

113. Sitkin, S. B., \& Bies, R. J. (1993). Social accounts in conflict situations: Using explanations to manage conflict. Human Relations, 46, 349-370. 
114. Slaughter JE, Sinar EF, Bachiochi PD. (2002). Black applicants' reactions to affirmative action plans: Effects of plan content and previous experience with discrimination, Journal of Applied Psychology, 87, $333-344$.

115. Society for Human Resource Management (2005) Workplace Diversity Practices: Survey Report. http://www.shrm.org/Research/SurveyFindings/Articles/Documents/050509WkplcDivPrcSR_FINAL_rev.pdf

116. Spanierman, L.B., Neville, H.A., Liao, H.Y., Hammer, J.H., \& Wang, Y.F. (2008). Participation in formal and informal campus diversity experiences effects on students' racial democratic beliefs. Journal of Diversity in Higher Education, 1, 108-125.

117. Steinberg, A. G., Iezzoni, L. I., Conill, A., \& Stineman, M. (2002). Reasonable accommodations for medical faculty with disabilities. The Journal of the American Medical Association, 288, 3147-3154,

118. Swann, W. B., Jr., Polzer, J. T., Seyler, D. C., \& Ko, S. J. (2004). Finding value in diversity: Verification of personal and social self-view in diverse groups. Academy of Management Review, 29, 9-27.

119. Swann, W. B. Jr., Rentfrow, P. J., \& Guinn, J. S. (2005). Self-verification: The search for coherence. In M. R Leary, \& J. P. Tangney (Eds.), Handbook of Self and Identity (pp. 367-383), New York: The Guilford Press.

120. Tajfel, H., \& Turner, J.C. (1986). The social identity theory of intergroup behavior. In S. Worchel, \& W.G. Austin (Eds.), Psychology of intergroup relations (pp. 7-24), Chicago: Nelson.

121. Think Beyond the Label (2010). http://www.thinkbeyondthelabel.com/

122. Thomas, K. M., \& Wise P. G. (1999). Organizational attractiveness and individual differences: Are diverse applicants attracted by different factors? Journal of Business and Psychology, 13, 375-390.

123. Triandis, H. C., Kurowski, L. L., \& Gelfand, M. J. (1994). Workplace diversity. In Trandis, M. D. Dunnette, L. M. Hough (Eds.), Handbook of Industrial and_Organizational Psychology and Social Psychology,_(Vol. 4, pp. 769-827), Palo Alto, CA: Consulting Psychologists Press.

124. Turner, J. C., Hogg, M. A., Oakes, P. J., Reicher, S. D., \& Wetherell, M. S. (Eds.) 1987. Rediscovering the social group. Oxford: Blackwell.

125. UNESCO (2002). UNESCO Universal Declaration on Cultural Diversity. http://unesdoc.unesco.org/images/0012/001271/127160m.pdf

126. UNESCO (2010). Communication and Information Activities. http://portal.unesco.org/ci/en/ev.phpURL_ID=1295\&URL_DO=DO_TOPIC\&URL_SECTION=201.html

127. Van den Bos, K. (2001). Uncertainty management: The influence of uncertainty salience on reactions to perceived procedural fairness. Journal of Personality and Social Psychology, 80, 931-941.

128. Van Dick, R., van Knippenberg, D., Hägele, S., Guillaume, Y. R. F., \& Brodbeck, F. C. (2008). Group diversity and group identification: the moderating role of diversity beliefs. Human Relations, 61, 14631492.

129. Van Knippenberg, D., De Dreu, C.K.W., \& Homan, A. C. (2004). Work group diversity and group performance: An integrative model and research agenda. Journal of Applied Psychology, 89, 1008-1022.

130. Van Maanen, J., \& Schein, E. H. (1979). Toward a theory of organizational socialization. In B. M. Staw (Ed.), Research in organizational behavior (Vol. 1, pp. 209-264). Greenwich, CT: JAI Press.

131. Wentling, R. M., \& Palma-Rivas, N. (2000). Current status of diversity initiatives in selected multinational corporations. Human Resource Development Quarterly, 11, 35-60.

132. Williams, K. \& O'Reilly, C.A. (1998). Demography and diversity: A review of 40 years of research. In B. Staw and R. Sutton (Eds.) Research in organizational behavior, 20, pp77-140. Greenwich, CT: JAI Press. 